\title{
Anticancer activity of a novel methylated analogue of $L$-mimosine against an in vitro model of human malignant melanoma
}

\author{
Sotiris Kyriakou ${ }^{1} \cdot$ Melina Mitsiogianni $^{1} \cdot$ Theodora Mantso $^{1} \cdot$ William Cheung ${ }^{1} \cdot$ Stephen Todryk ${ }^{1}$. \\ Stephany Veuger ${ }^{1} \cdot$ Aglaia Pappa $^{2} \cdot$ David Tetard $^{1} \cdot$ Mihalis I. Panayiotidis $^{1} \mathbb{D}$
}

Received: 3 April 2019 / Accepted: 5 June 2019/Published online: 26 June 2019

(C) The Author(s) 2019

\section{Summary}

The anticancer activity of a series of novel synthesized, hydroxypyridone-based metal chelators (analogues of $L$-mimosine) was evaluated in an in vitro model of melanoma consisting of malignant melanoma (A375), non-melanoma epidermoid carcinoma (A431) and immortalized non-malignant keratinocyte (HaCaT) cells. More specifically, we have demonstrated that the $L$-enantiomer of a methylated analogue of $L$-mimosine (compound 22) can exert a potent anticancer effect in A375 cells when compared to either A431 or HaCaT cells. Moreover, we have demonstrated that this analogue has the ability to i) promote increased generation of reactive oxygen species (ROS), ii) activate both intrinsic and extrinsic apoptosis and iii) induce perturbations in cell cycle growth arrest. Our data highlights the potential of compound 22 to act as a promising therapeutic agent against an in vitro model of human malignant melanoma.

Keywords Metal chelators $\cdot L$-mimosine analogues $\cdot$ Skin cancer $\cdot$ Anticancer activity $\cdot$ Melanoma

\section{Introduction}

Skin cancer is categorized into three main types based on their cellular localization and clinical behavior including basal and squamous cell carcinoma as well as melanoma $[1,2]$. In particular, malignant melanoma is a tumor arising in melanocytes and once in the progressive stage it can invade and penetrate beyond the dermis layer [3]. Metastasis occurs in the lymph nodes and/ or distant sites like lungs, liver and nervous system and therefore development of clinically effective therapeutic strategies is of utmost importance [4]. Despite the fact that transition metals

Electronic supplementary material The online version of this article (https://doi.org/10.1007/s10637-019-00809-0) contains supplementary material, which is available to authorized users.

Mihalis I. Panayiotidis

m.panagiotidis@northumbria.ac.uk

David Tetard

david.tetard@northumbria.ac.uk

1 Department of Applied Sciences, Northumbria University, Newcastle Upon Tyne, UK

2 Department of Molecular Biology \& Genetics, Democritus University of Thrace, Alexandroupolis, Greece have a significant importance in maintaining health, they can also contribute into the development and progression of many types of cancer. For example, elevated copper levels can promote tumor development, angiogenesis and metastasis while other studies have shown the importance of such elevation in the formation of soluble extracellular E-cadhenin fragment (sECAD) that is implicated in cancer cell invasion [5-8]. In the case of iron, reactive oxygen species (ROS) are formed and shown to be involved in carcinogenesis by various means including overexpression of proteins participating in angiogenesis and metastasis (e.g. SNAIL, AP-1 and VEGF), activation of the oncogenic NF-KB pathway and others [9-13]. Finally, zinc overload, can lead to overexpression of zinc-depended enzymes like matrix metalloproteinases (MMPs) that can degrade components of the extracellular matrix (ECM) thus further contributing to angiogenesis and metastasis [14, 15].

For this reason, it is not surprising that metal chelators are being considered as anticancer agents by restoring metal homeostasis and consequently inhibiting i) cell growth, ii) intracellular ROS formation and iii) cell proliferation [16, 17]. As a result, a variety of them have been synthesized (e.g. deferiprone; DFP [18], desferrioxamine; DFO [19], tachpyridine [20], triapine [21] and 2-hydroxy-1-naphthyl aldehyde isonocitinyl hydrazine [22]) all of which are capable of acting as anticancer agents (Fig. 1a). However, the difficulty associated with their 


\section{a}<smiles>Cc1c(O)c(=O)ccn1C</smiles>

(1)

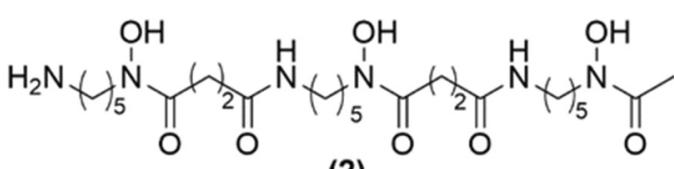

(2)<smiles>NC(=S)N/N=C/c1ncccc1N</smiles>

(4)<smiles>c1ccc(CNCC2CC(CNCc3ccccn3)C(CNCc3ccccn3)C2)nc1</smiles>

(3)

b<smiles>N[C@@H](Cn1ccc(=O)c(O)c1)C(=O)O</smiles>

(6)

Fig. 1 a Structural representation of selective metal chelators with anti-cancer properties. Deferiprone (DFP) (1), Desferrioxamine (DFO) (2), Tachpyridine (3), Triapine (4) and 2-hydroxy-1-naphthyl aldehyde isonocitinyl hydrazone (5); b Structure of L-mimosine (6)

development is the risk for potential side-effects due to their ability to interact with various metalloproteins. For example, DFP used in the treatment of iron overload is known to inhibit lipoxygenase and tyrosine hydroxylase and is also associated with agranulocytosis [23-25].

$L$-mimosine is a natural 3-hydroxy-4(1H)pyridinone $(3,4-$ HOPO) iron chelator containing an amino acid side chain (Fig. 1b) that is derived from the plants Mimosa and Leucaena genara endowed with a range of bioactivities including anti-cancer, anti-inflammatory, anti-viral, anti-fibrotic, etc. [26, 27]. Previously, $L$-mimosine was shown to i) inhibit tyrosinase and thyroxine decarboxylases, ii) induce cell death and cell cycle growth arrest, iii) suppress elongation of DNA replication, iv) disrupt deoxyribonucleotide metabolism and v) inhibit the transcription of serine hydroxymethyltransferase [28-39]. Finally, $L$-mimosine has been shown to exert anticancer activity against various melanoma cell lines and although initially appeared as a potentially attractive anticancer agent, its marked cytotoxic sideeffects have discouraged its further development [40-42].
To the best of our knowledge, there are no reports on how $L$ mimosine can enter cells. However, being a close analogue of $L$ DOPA, it may be that it acts as a substrate of the large neutral amino acids' transporter namely LAT-1 which is known to possess a wide substrate specificity including $L$-DOPA [43-46]. Interestingly, LAT-1 is overexpressed in various cancer cells thus providing an opportunity to specifically target them [47]. To combat the side-effects of $L$-mimosine it is, however, necessary to identify safer analogues. In particular, the 3,4-HOPO chelating moiety can be replaced by relevant isomers such as 1-hydroxy2(1H)- pyridinone (1,2-HOPO) and 3-hydroxy-2(1H)pyridinone $(3,2-\mathrm{HOPO})$ or the less powerful coordinating group 3-hydroxy-4-pyranone. As the ligand binding pocket of LAT-1 has hydrophobic domains provided by residues F252, F402 and V148, L-mimosine can also be made more lipophilic to help target the LAT-1 transport mechanism [46].

The aim of the current study was to i) design and synthesize a series of $L$-mimosine analogues and ii) assess their anticancer activity (e.g. viability, apoptosis, necrosis, ROS and cell 
cycle growth arrest) in an in vitro model of human malignant melanoma consisting of melanoma (A375), non-melanoma (A431) and non-malignant immortalized keratinocyte (HaCaT) cells. The latter cell line was utilized as a control, non-malignant one (predominantly existing in the epidermis thereby surrounding a malignant melanocyte) allowing us to determine potential "side" cytotoxicity. Finally, the nonmelanoma cells provide a means of assessing the specificity of an observed anticancer activity between melanoma and non-melanoma skin cancer cells.

\section{Materials and methods}

\section{Chemicals, equipment and organic synthesis}

All chemical reagents were purchased from Sigma-Aldrich (St. Louis, MO, USA), Alfa Aesar (Lancashire, UK), Fluorochem (Derbyshire, UK), TCI (Oxford, UK) and were used without any further purification. All chemical solvents were purchased from Fisher Scientific (Hampton, NH, USA) and Sigma Aldrich (St. Louis, MO, USA), at either HPLC or reagent grade. When required, solvents were dried over activated $4 \AA$ molecular sieves.

NMR Spectroscopy was performed on JEOL ELS400 Delta Spectrometer at frequencies of $400 \mathrm{MHz}$ for ${ }^{1} \mathrm{H}$ NMR, $101 \mathrm{MHz}$ for ${ }^{13} \mathrm{C}$ NMR. Chemical shifts were recorded as parts per million (ppm) with tetramethylsilane (TMS) as the internal standard. Solvents used included deuterated dimethyl sulfoxide (DMSO- $\left.d_{6}\right)$, deuterated chloroform $\left(\mathrm{CDCl}_{3}\right)$, deuterated methanol $\left(\mathrm{MeOH}-d_{4}\right)$, deuterated water $\left(\mathrm{D}_{2} \mathrm{O}\right)$ and deuterated TFA $\left(\mathrm{CF}_{3} \mathrm{CO}_{2} \mathrm{D}\right)$. Chemical shifts were observed with integrals, splitting and $\mathrm{J}$ values, multiplicity of the signals were recorded as singlet (s), doublet $(\mathrm{d})$, triplet $(\mathrm{t})$, quartet $(\mathrm{q})$. In addition, the multiplicities (which have further coupling) were recorded e.g. double doublet (dd). High Resolution Mass Spectrometry (HRMS) was performed on Thermo Q-Exactive spectrometer with electrospray ionisation (ESI) (Thermo Fisher Scientific, Cramlington, UK) while High Performance Liquid Chromatography (HPLC) (Agilent Technologies, 1260 Infinity) analysis was carried out on a Phenomenex Column (HYPERSIL 5u C18, $150 \times 4.60$ mm). Flash Chromatography was performed on Biotage ${ }^{\circledR}$ Isolera One using Biotage ${ }^{\circledR}$ SNAP-Ultra flash chromatography cartridges 10-100 g size (Biotage, Uppsala, Sweden).

Finally, detailed description of the synthesis and characterization of the screened molecules is shown in the Supplementary Material.

\section{Cell lines}

The human malignant melanoma (A375) and epidermoid carcinoma (A431) cell lines were purchased from Sigma-Aldrich
(St. Louis, MO, USA). The human immortalized keratinocyte (HaCaT) cell line was kindly provided by Dr. Broby (Public Health England, UK). All cell lines were authenticated with the STR method and were also tested for mycoplasma contamination. In addition, they were maintained in DMEM medium with high glucose content, supplemented with $10 \%$ FBS, 2 mM L-glutamine, and $1 \%$ pen/strep (100 U/mL penicillin, $100 \mu \mathrm{g} / \mathrm{mL}$ streptomycin) and cultured in a humidified atmosphere at $37{ }^{\circ} \mathrm{C}$ and $5 \% \mathrm{CO}_{2}$, grown as monolayers and sub-cultured at 80-90\% confluency. All cell lines were cultured for 15-20 passages before new stocks were utilized. Finally, all media and reagents were purchased from Labtech (East Sussex, UK) whereas all cell culture plasticware were obtained from Corning (Corning, NY, USA).

\section{Determination of cell viability}

The Alamar-blue assay was utilized in this set of experiments. Briefly, A375, A431, and HaCaT cells were seeded in $100 \mu \mathrm{L} /$ well into 96-well plates and incubated overnight prior to exposure to each of the hydroxypyridone compounds (e.g. compounds 10, 11, 18, 22, 23 and 29). Density of A375 cells was 8000, 4000, 2000 cells/well and for A431 and HaCaT cells $10,000,5000,2500$ cells/well for 24,48 and $72 \mathrm{~h}$, respectively. On the following day, cells were exposed to a range of concentrations $(10-1000 \mu \mathrm{M})$ over different incubation periods. For control conditions, cells were incubated with complete medium only. At the indicated time points, resazurin [dissolved in PBS ( $1 \mathrm{mg} / \mathrm{ml}$ final concentration)] was added in an amount equal to $1 / 10$ of the volume in each well and incubated for 2-4 h (depending on the type of cancer cell line), at $37{ }^{\circ} \mathrm{C}$. The plates were then centrifuged, and absorbance was recorded at $570 \mathrm{~nm}$ and $600 \mathrm{~nm}$ (reference wavelength) using a Spark multimode plate reader (Tecan, Switzerland). The levels of cell viability were estimated and expressed as percentage of control cells.

\section{Morphological observation of cells}

A375 cells were seeded in $100 \mathrm{~mm}$ dishes and exposed to either complete medium only (control) or $100 \mu \mathrm{M}$ of compound 22 for 24,48 and $72 \mathrm{~h}$. The density of A375 cells was $1.4 \times 10^{6}, 0.7 \times 10^{6}$ and $0.4 \times 10^{6}$ per dish for 24,48 and $72 \mathrm{~h}$, respectively. At the indicated time points, the morphology of cells was observed by an inverted phase contrast microscope (ZOE fluorescent cell imager, Bio-rad, CA, USA) and images were captured at 20x magnification.

\section{Determination of ROS}

A375 cells were seeded in $100 \mathrm{~mm}$ dishes $\left(1.4 \times 10^{6}, 0.7 \times\right.$ $10^{6}$ and $0.4 \times 10^{6}$ per dish for 24,48 and $72 \mathrm{~h}$, respectively) and exposed to $100 \mu \mathrm{M}$ of compound 22 . Then, they were 
harvested and washed twice with PBS and a single cell suspension of $10^{6}$ cells $/ \mathrm{mL}$ was prepared. Dihydrorhodamine 123 (DHR 123;10 $\mu \mathrm{M}$ ) was added in the suspension and incubated for $5 \mathrm{~min}$ at $37^{\circ} \mathrm{C}$. Then, DAPI $(1 \mu \mathrm{M})$ was added to each sample and incubated for $5 \mathrm{~min}$ in order to determine the percent of dead cells in the suspension. Data acquisition and analysis of 10,000 events, for each sample, was performed using a FACS Canto II flow cytometer (BD Biosciences, San Jose, CA, USA). DAPI-positive cells were excluded from further analysis of the results.

\section{Determination of apoptosis}

The CellEvent Caspase 3/7 Green flow cytometry assay kit was utilized for the detection of apoptosis according to the manufacturer's instructions. Briefly, cells were plated into $100 \mathrm{~mm}$ dishes and allowed to adhere overnight. Density of A 375 cells was $1.4 \times 10^{6}, 0.7 \times 10^{6}$ and $0.4 \times 10^{6}$ cells per dish for 24,48 and $72 \mathrm{~h}$, respectively. The next day, cells were exposed to $100 \mu \mathrm{M}$ of compound 22 for 24,48 and $72 \mathrm{~h}$. Next, cells were harvested, washed twice with PBS and a single cell suspension of $10^{6}$ cells $/ \mathrm{mL}$ was prepared. Then, $0.5 \mu \mathrm{L}$ of CellEvent Caspase 3/7 Green detection reagent was added into $0.5 \mathrm{~mL}$ of each cell suspension and samples were incubated at $37^{\circ} \mathrm{C}$ for $30 \mathrm{~min}$. Five (5) min prior to the end of the incubation period, $1 \mu \mathrm{M}$ of DAPI was added. Data acquisition and analysis of 20,000 events, for each sample, was performed using a FACS Canto II flow cytometer (BD Biosciences, San Jose, CA, USA). Caspase-3/7-positive cells were identified as apoptotic whereas DAPI-positive cells as necrotic.

\section{Determination of cell cycle kinetics}

The FxCycle PI/RNase staining solution was used according to the manufacturer's instructions. Following exposure to $100 \mu \mathrm{M}$ of compound 22, cells were harvested and washed twice with PBS. The density of A375 cells was $1.4 \times 10^{6}$, $0.7 \times 10^{6}$ and $0.4 \times 10^{6}$ cells per dish for 24,48 and $72 \mathrm{~h}$, respectively. Approximately $0.5 \times 10^{6}$ cells were fixed in cold $70 \%$ ethanol, for $1 \mathrm{~h}$ or longer, at $4{ }^{\circ} \mathrm{C}$ until further processing. Cells were then washed twice with PBS to remove ethanol and finally suspended in FxCycle PI/RNase staining solution for $30 \mathrm{~min}$ at RT in the dark. Data acquisition and analysis of 10,000 events, for each sample, was performed using a FACS Canto II flow cytometer (BD Biosciences, San Jose, CA, USA).

\section{Preparation of cell lysates and protein determination}

A375 cells were plated in $100 \mathrm{~mm}$ dishes and cultured overnight at $37^{\circ} \mathrm{C}$ at a density of $1.4 \times 10^{6}, 0.7 \times 10^{6}$ and $0.4 \times 10^{6}$ cells per dish for 24,48 and $72 \mathrm{~h}$ respectively Next day, cells were treated with $100 \mu \mathrm{M}$ of compound 22 for 24,48 and $72 \mathrm{~h}$ and then trypsinized, washed twice with ice-cold PBS and pellets were collected after centrifugation at $2000 \mathrm{rpm}$ for 3 min at $4{ }^{\circ} \mathrm{C}$. Cell pellets were then lysed in lysis buffer (10 mM HEPES at $\mathrm{pH} 7.9,10 \mathrm{mM} \mathrm{KCl}, 0.1 \mathrm{mM}$ EDTA, $1.5 \mathrm{mM} \mathrm{MgCl}_{2}, 0.2 \% \mathrm{NP} 40$ ) and supplemented with Protease Inhibitor Tablets (Thermo Scientific, Waltham, MA, USA). Then, they were left on ice while periodically vortexed over a $30 \mathrm{~min}$ period and sonicated (three cycles at 10 amplitudes for $20 \mathrm{~s}$ on ice) to disrupt cellular membranes. Cell lysates were centrifuged at full speed $(15,000 \mathrm{rpm})$ for 10 min at $4{ }^{\circ} \mathrm{C}$ and supernatants were transferred in new tubes. Protein content was determined by utilizing the BCA protein assay kit (Thermo Scientific, Waltham, MA, USA), according to the manufacturer's protocols. Protein extracts were stored at $-20{ }^{\circ} \mathrm{C}$ until usage.

\section{Western immunoblotting}

Forty micrograms $(40 \mu \mathrm{g})$ of cytoplasmic protein extracts were separated by SDS-polyacrylamide gels and transferred electrophoretically onto PVDF membranes (either 0.45 or $0.2 \mu \mathrm{m}$ ) using mini gel tank sand mini blot modules (Invitrogen, Carlsbad, CA, USA). The blots were then blocked in 5\% non-fat milk powder in TBST buffer $(50 \mathrm{mM}$ Tris- $\mathrm{HCl}, 150 \mathrm{mM} \mathrm{NaCl}$ at $\mathrm{pH} 7.6$ and $0.1 \%$ Tween-20) for $2 \mathrm{~h}$ at RT. After blocking, membranes were washed three times with TBST and incubated overnight at $4{ }^{\circ} \mathrm{C}$, under agitation, with the appropriate primary antibody (e.g. 1:1000 for anti-Caspase-8, anti-Caspase-9, anti-Apaf-1, anti-BID, and 1:20000 for anti-Tubulin) and according to the manufacturer's protocol. All antibodies were purchased from Cell Signaling Technology (Danvers, MA, USA). Next day, membranes were incubated with the appropriate horseradish peroxidaseconjugated secondary antibody (mouse or rabbit at 1:1000) for $1 \mathrm{~h}$ at RT, under agitation, after being washed three times with TBST. Membranes were washed three times with TBST and labelled protein bands were detected by utilizing the SuperSignal West Pico PLUS Chemiluminescent Substrate kit from Thermo Scientific (Waltham, MA, USA) according to the manufacturer's protocol. Protein bands were visualized with the use of the G:BOX Chemi XX6/XX9 gel imaging system (Syngene, Cambridge, UK).

\section{Statistical analysis}

Data were expressed as mean values \pm standard deviation (SD) and comparisons were made between control and treated groups. Statistical analyses were performed by one-way ANOVA with Tukey's test for multiple comparisons after using the SPSS v.22 software. Finally, statistical significance was set at $p<0.05, p<0.01$ and $p<0.001$. 


\section{Results}

The anticancer activity of a number of hydroxypyridinone (HOPO) core metal chelators was evaluated in human malignant melanoma (A375) cells including those of 1,2-HOPO (compound 18), 2,3-HOPO (compound 29), 3,4-HOPO (compounds $11,22,23$ ) and hydroxypyranone (compound 10 ). Each compound was assessed at a range of concentrations $(10-1000 \mu \mathrm{M})$ and time points $(24-72 \mathrm{~h})$. Our results revealed that A375 cells were resistant to exposure with compounds 10 and 29 while compounds 11 and 18 only showed noteworthy activity at concentrations as high as $1000 \mu \mathrm{M}$, after $72 \mathrm{~h}$ treatment (Figs. 2a-d). However, compounds 22 and 23 showed significant time- and concentration-dependent cytotoxicity.
More specifically, cell viability levels reached an $\mathrm{EC}_{50}$ at a concentration of $100 \mu \mathrm{M}$ after 48 and $72 \mathrm{~h}$ of exposure to compounds 22 and 23 respectively (Figs. 2e and f). Furthermore, at $24 \mathrm{~h}$ of exposure with compounds 22 and 23 cell viability levels were either decreased or remained almost at control levels respectively. Overall, treatment with compound 22 was more potent $\left(\mathrm{EC}_{50}\right.$ value of $\left.100 \mu \mathrm{M}\right)$ when compared to compound 23 ( $\mathrm{EC}_{50}$ value of approximately $250 \mu \mathrm{M}$ ), after $48-72 \mathrm{~h}$ of exposure, an observation which was also evident under inverted phase contrast microscopy (Fig. 3). Although it is well established that both enantiomers have similar activity, the preference for the $L$-enantiomer (compound 22) is likely explained by the slight preference of LAT-1 for the $L$-enantiomers of amino acids [44].

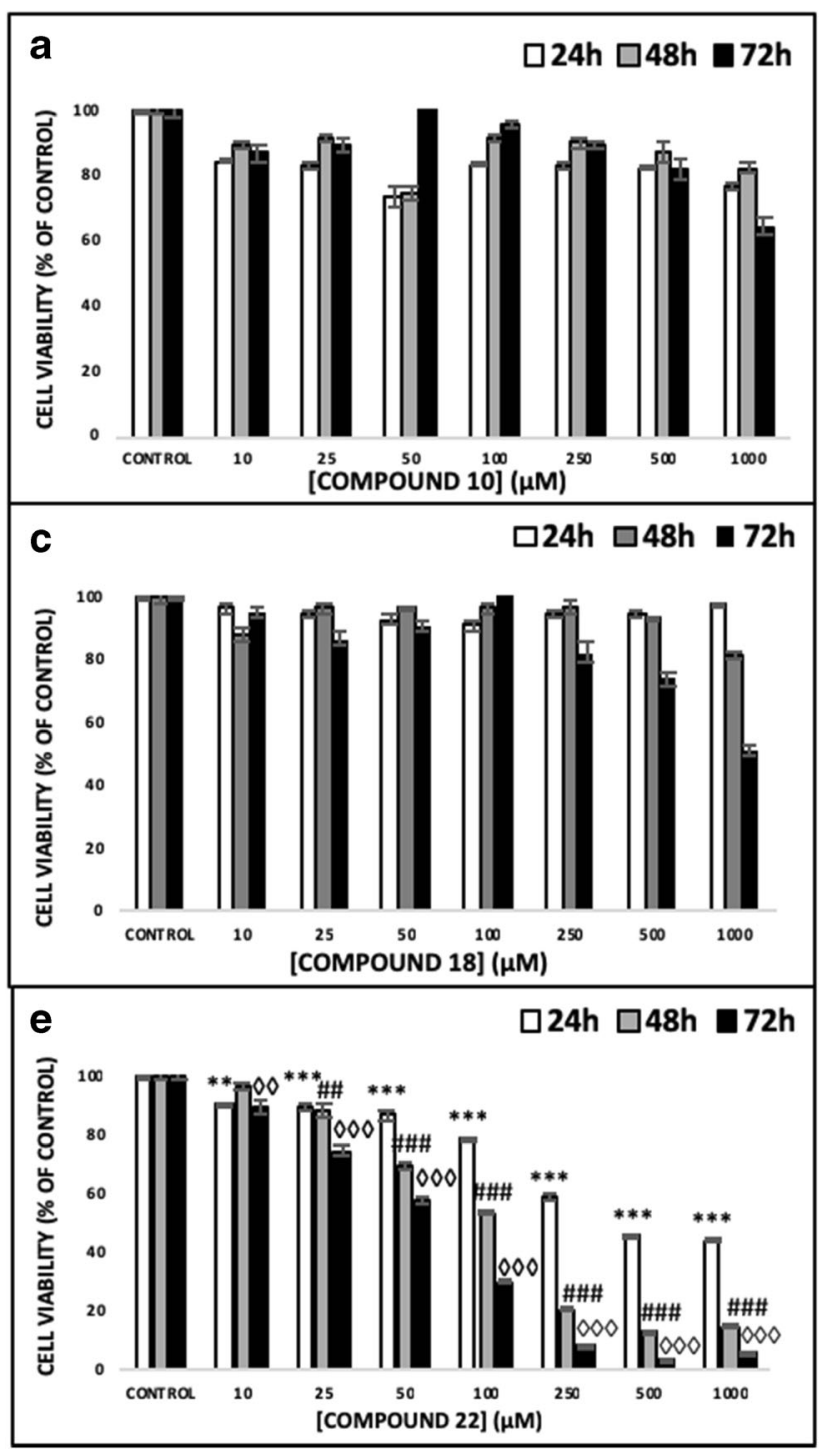

Fig. 2 The ability of hydroxypyridones to induce cytotoxicity in A375 cells. Cells were exposed to a range of 10-1000 $\mu \mathrm{M}$ concentrations of (a) compound 10, (b) compound 11, (c) compound 13, (d) compound 29, (e) compound 22 and (f) compound 23 for 24,48 and $72 \mathrm{~h}$. Data shown are

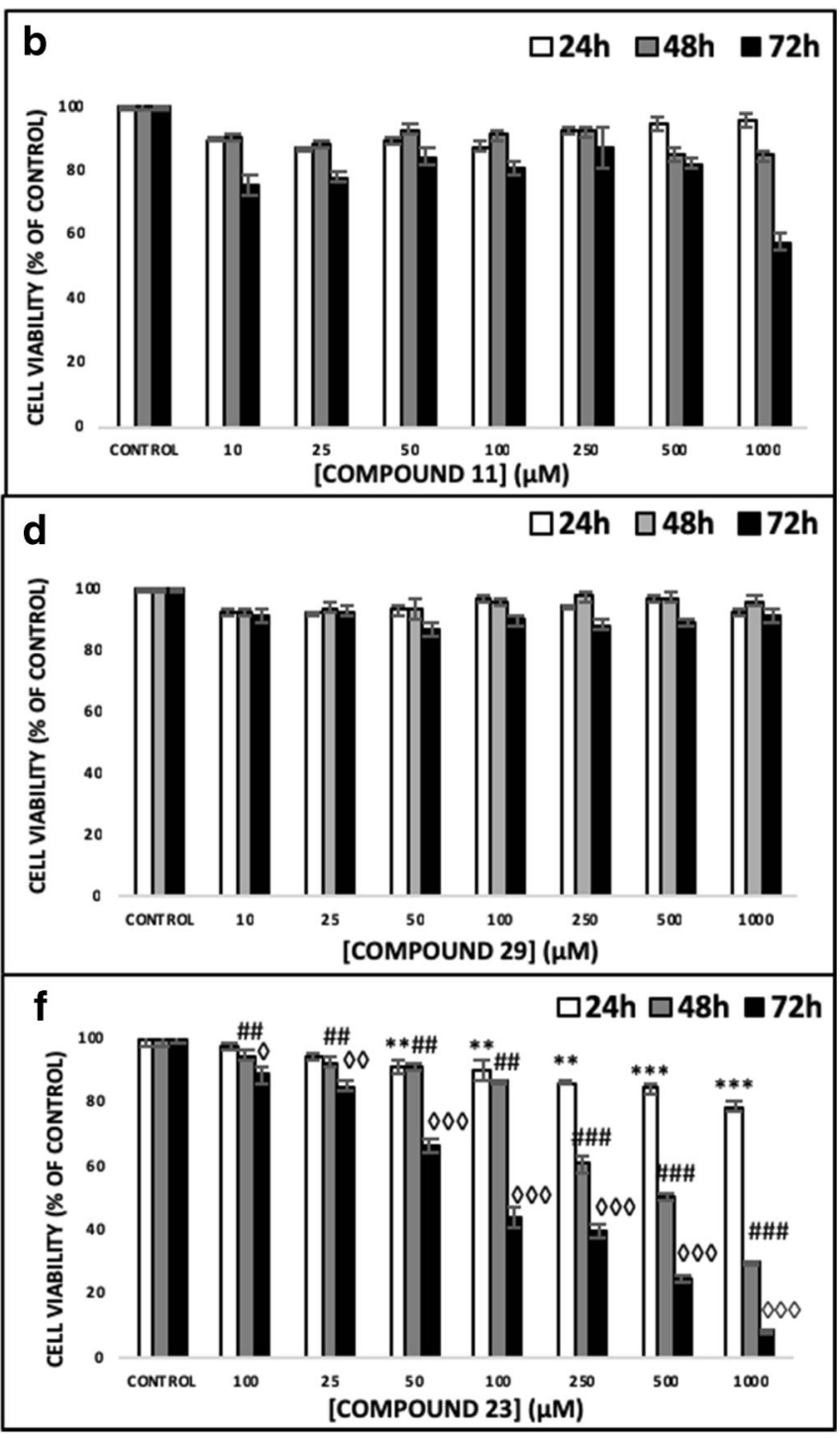

means \pm SD of 5 replicates from three independent experiments. Asterisk $(*)$, hashtag (\#) or rhombus $(\diamond)$ denote statistical significance when compared to their respective controls at $p<0.05$. **, \#\# and $\diamond \diamond$ denote statistical significance at $p<0.01$ whereas $* * *, \# \#, \diamond \diamond \diamond$ at $p<0.001$ 

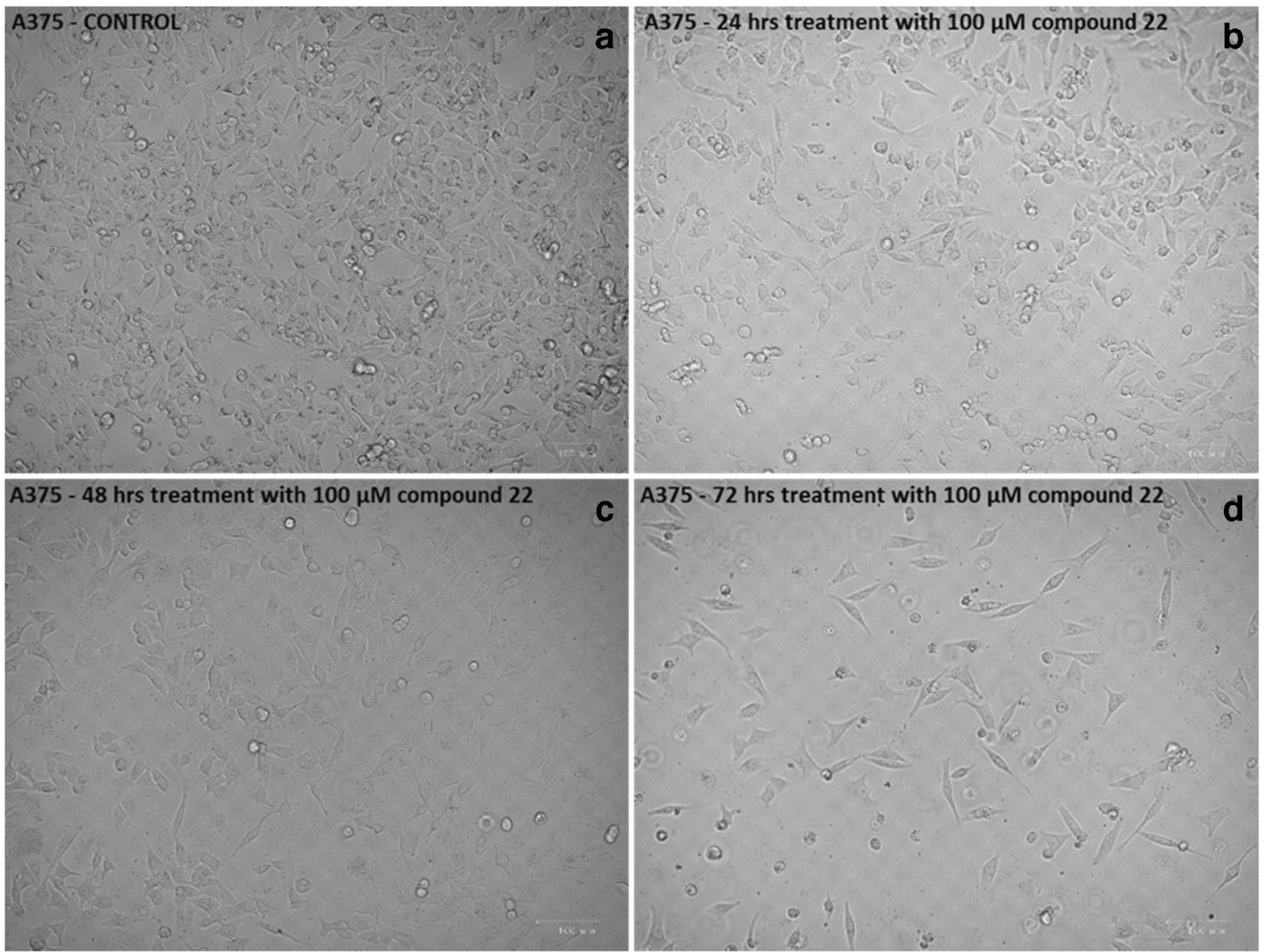

Fig. 3 The ability of compound 22 to induce cytotoxicity in A375 cells. Control cells (a) and those exposed to $100 \mu \mathrm{M}$ of compound 22 at $24 \mathrm{~h}$ (b), $48 \mathrm{~h}$ (c) and $72 \mathrm{~h}$ (d) were visualized under inverted phase contrast microscope

Interestingly, the observed order of activity (compounds 22 and $23>>$ compound $18>$ compound $11>$ compound $10=$ compound 29) does not match the order expected only from their metal binding efficiency $(3,4-\mathrm{HOPO}>>3,2-\mathrm{HOPO} \approx$ 1,2 - HOPO $>$ hydroxypyranones) [44-47]. This suggests that the activity is guided by a more complex combination of molecular properties. Finally, we evaluated the observed cytotoxic potency of compound 22 (at $100 \mu \mathrm{M}$ ) in non-melanoma (A431) as well as non-malignant keratinocyte (HaCaT) cells in an attempt to document any potential specificity towards A375 cells. Our observations revealed that A431 and HaCaT cells were also affected by compound 22 but nevertheless were shown to be more resistant than A375 cells (Figs. 4a and b). Taken together, our data indicate that compound 22 exerts a higher degree of potency against A375 cells while $\mathrm{A} 431$ and $\mathrm{HaCaT}$ cells remain considerably more resistant.

On the other hand, the ability of compound 22 to induce intracellular ROS generation was also evaluated by means of flow cytometry and after utilizing a fluorescent DHR 123 probe as a ROS detector. Our data showed that the FITC spectrum increased dramatically in the exposed group compared to the unexposed (control) one (Fig. 5a). Interestingly, treatment of A375 cells with $100 \mu \mathrm{M}$ of compound 22 induced a significant increase in intracellular ROS levels, during the first $24 \mathrm{~h}$, which were sustained at each time point thereafter (Fig. 5b).

Moreover, the number of apoptotic and necrotic A375 cells was evaluated after exposure to compound 22. To distinguish between these two modes of cell death, the CellEvent Caspase 3/7 Green detection reagent was utilized as an activated caspase 3/7 activity indicator whereas DAPI as an indicator for necrosis (Fig. 6a). Our data showed significant cell death during the first $24 \mathrm{~h}$, an effect which was intensified (over time) in a manner where live cells were reduced while necrotic cells remained at steady levels (Fig. 6b). In addition, a more detailed characterization of various key proteins representative of the intrinsic and extrinsic apoptotic pathways was performed (by western immunoblotting) in A375 cells exposed to compound 22 (at $100 \mu \mathrm{M}$ ). The expression levels of cleaved and full length Caspase- 8 were indicative of the involvement of the extrinsic apoptotic pathway [48-51] whereas those of Caspase- 9 and Apoptotic protease-activating factor 1 (Apaf-1) for the intrinsic one [52-55]. In addition, expression levels of BID were reduced representative of the wellestablished interplay between the two apoptotic pathways [50]. Overall, the activation of Caspase- 8 was evident by the 
Fig. 4 The ability of compound 22 to induce cytotoxicity in (a) non-melanoma (A431) cells and (b) non-malignant keratinocyte (HaCaT) cells. Cells were exposed to $100 \mu \mathrm{M}$ of compound 22 for 24, 48 and $72 \mathrm{~h}$. Data shown are means $\pm \mathrm{SD}$ of 5 replicates from three independent experiments. Asterisk (*), hashtag (\#) or rhombus $(\diamond)$ denote statistical significance when compared to their respective controls at $p<0.05$. **, \#\# and $\diamond \diamond$ denote statistical significance at $\mathrm{p}<0.01$ whereas ***, \#\#\#, $\diamond \diamond \diamond$ at $p<0.001$
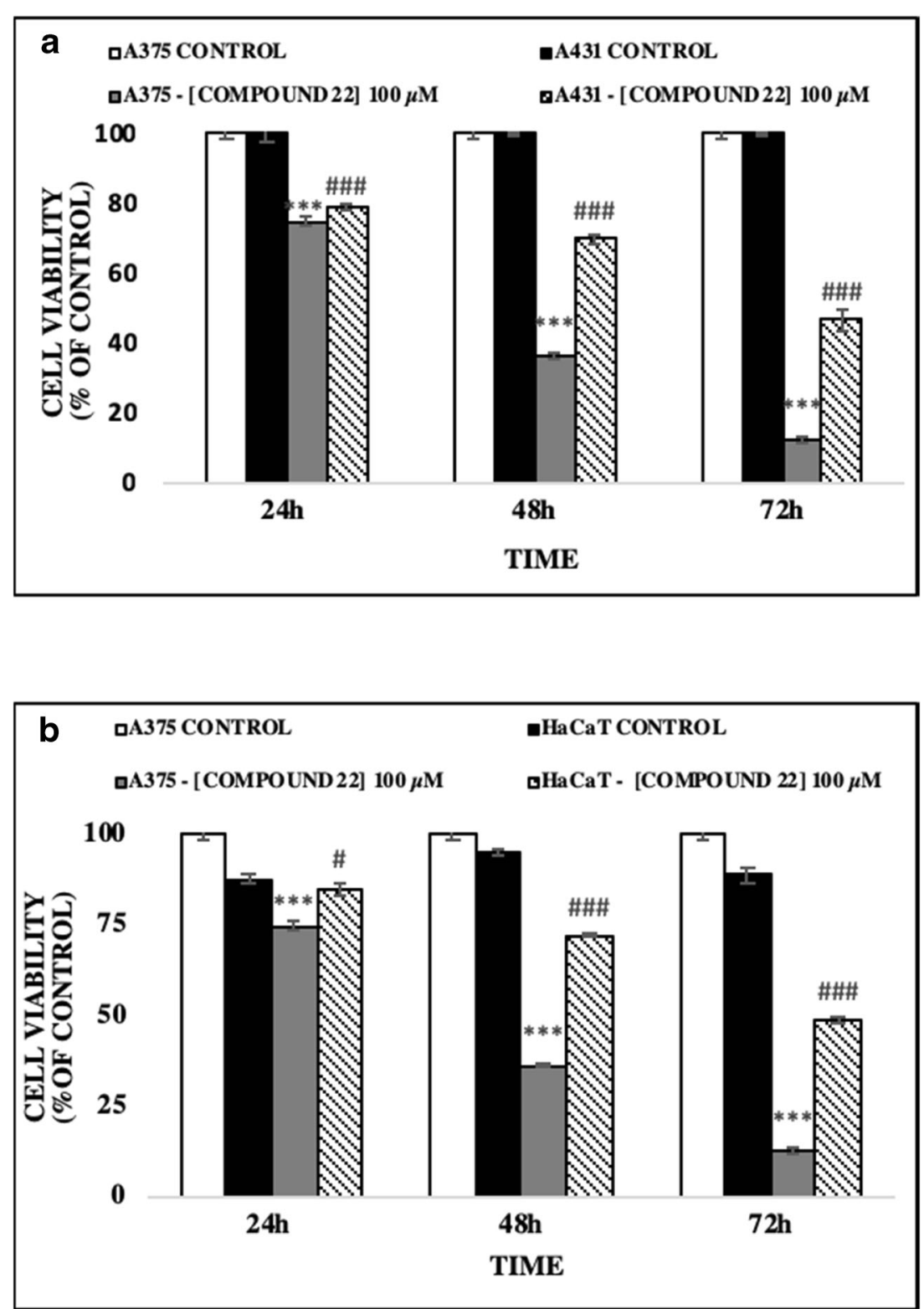

presence of increased cleaved and/or reduced un-cleaved "full" length protein expression levels observed as early as $24 \mathrm{~h}$ after exposure (and remained as such throughout the entire time-course) thus indicating the activation of the extrinsic apoptotic pathway (Fig. 6c). Furthermore, the expression levels of BID were also shown to be elevated at 24-48 h (indicative of a concomitant activation of the intrinsic apoptotic pathway) while were reduced back to control levels after $72 \mathrm{~h}$ of exposure (Fig. 6c). Further evidence for the concomitant activation of the intrinsic apoptotic pathway was revealed after examining the expression levels of Caspase-9 and Apaf1 throughout the time-course (Fig. 6c). To this end, several studies have shown that activation of Caspase- 8 as well as that of Caspase-9 and Apaf-1 (via formation of the apoptosome) can lead to the activation of Caspase- 3 which is an established mechanism for the execution of apoptosis [50-59].

Finally, the ability of compound 22 to induce cell cycle growth arrest was assessed by using the FxCycle PI/RNase staining solution for quantification of DNA content under each phase of the cell cycle and subsequent analysis by flow cytometry (Fig. 7a). Our results show that $24 \mathrm{~h}$ of exposure cause a statistically significant elevation of the G1 phase followed by a reduction of the G2/M phase while the $S$ phase remained unaffected. Interestingly, at $48 \mathrm{~h}$, a significant increase of the sub-G1 phase was also observed followed by a marked reduction of the $\mathrm{G} 1$ phase while the $\mathrm{S}$ - and G2/M phases remained relatively unaffected. Furthermore, this effect was intensified at $72 \mathrm{~h}$ of exposure (Fig. 7b). 
Fig. 5 The ability of compound 22 to induce generation of oxidative stress in A375 cells. Cells were exposed to $100 \mu \mathrm{M}$ of compound 22 for 24,48 and $72 \mathrm{~h}$ and monitored by means of (a) flow cytometry in addition to being quantitated as (b) ROS fold induction. Data shown are means $\pm \mathrm{SD}$ of 3 replicates from three independent experiments. Asterisks (***) denote statistical significance at $p<0.001$ when compared to the respective controls after of exposure
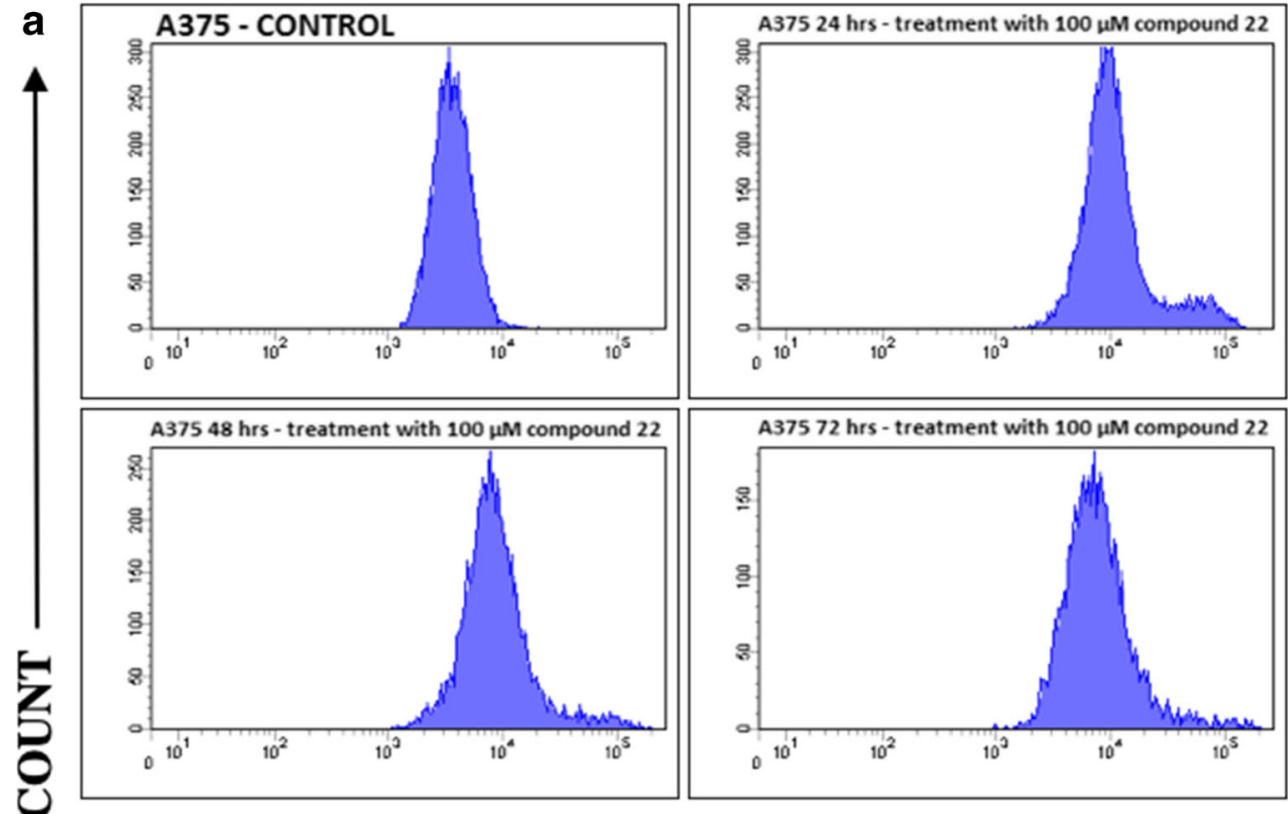

A375 72 hrs - treatment with $100 \mu \mathrm{M}$ compound 22

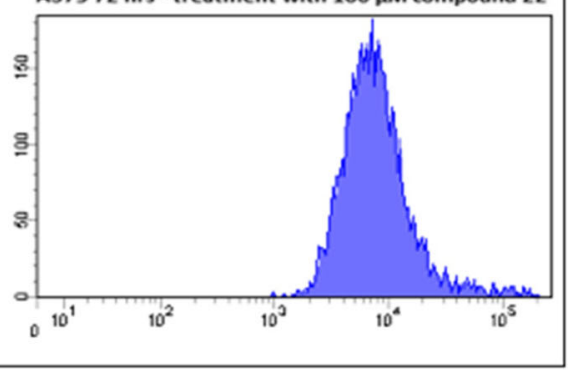

FITC (DHR) 123)

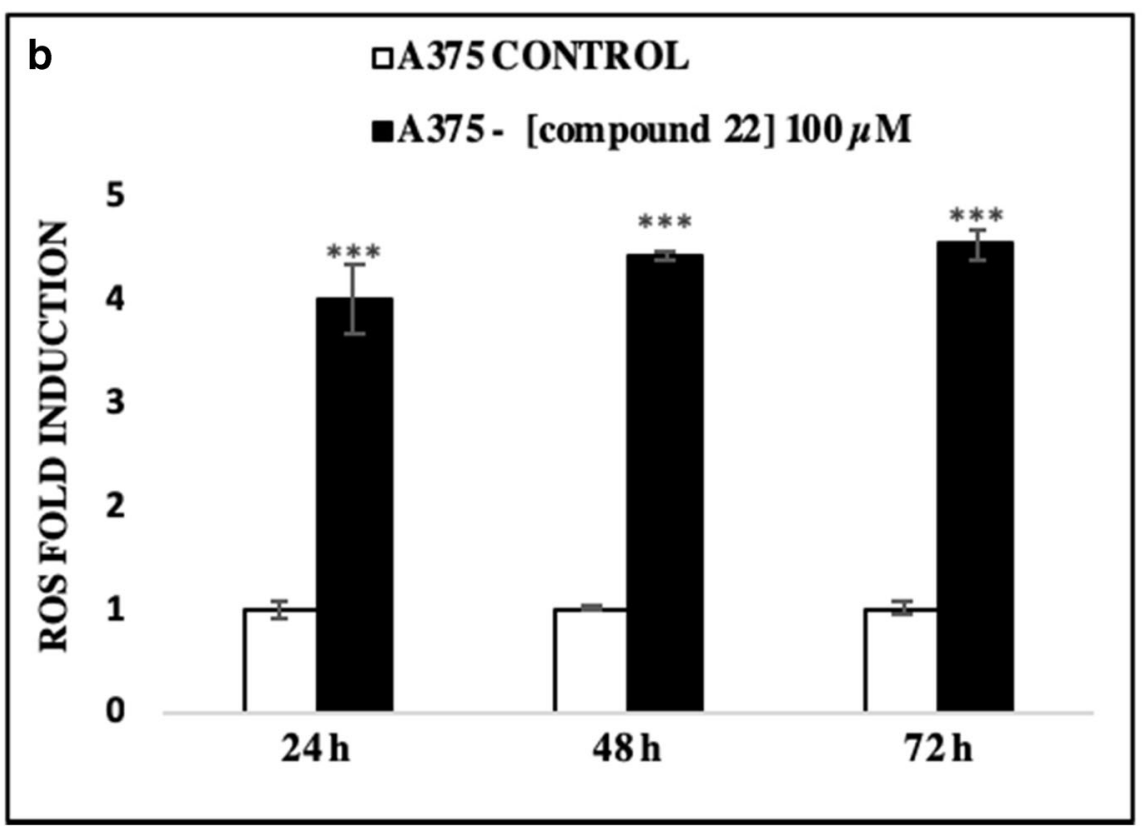

\section{Discussion}

The capacity of metal chelators to act as anticancer agents (and potentially as clinically effective treatment options) has been reported in various in vitro cancer models including malignant melanoma and leukemia $[60,61]$. During our study, a series of hydroxypyridinones-based analogues of $L$-mimosine were synthesized and their anticancer activity was evaluated against an in vitro model of human malignant melanoma. Of these, a methylated analogue ( $L-N$ - substituted 3.4-HOPO) of
$L$-mimosine (compound 22) was shown to be the most cytotoxic with a higher degree of potency in A375 cells compared to A431 and HaCaT cells. Previous experimental studies, utilizing dipeptides of $L$-mimosine against melanoma, suggested that the selectivity of this class of HOPO-based molecules was mainly due to their ability to inhibit and consequently downregulate tyrosinase which causes perturbations in melanin production $[62,63]$ the levels of which are increasing in metastatic melanoma thereby reducing the outcome of radiotherapy. On such basis, it has been postulated that inhibition of 

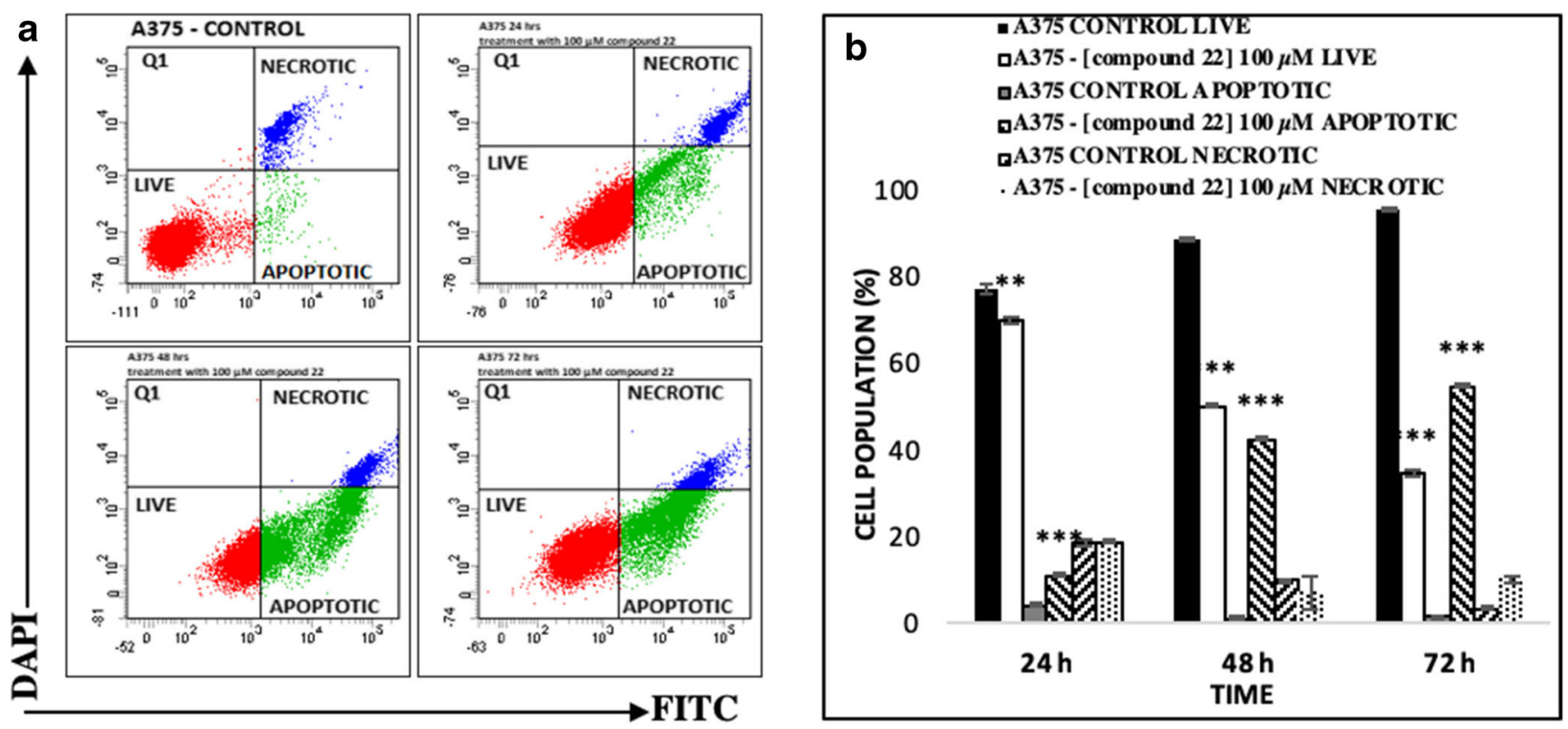

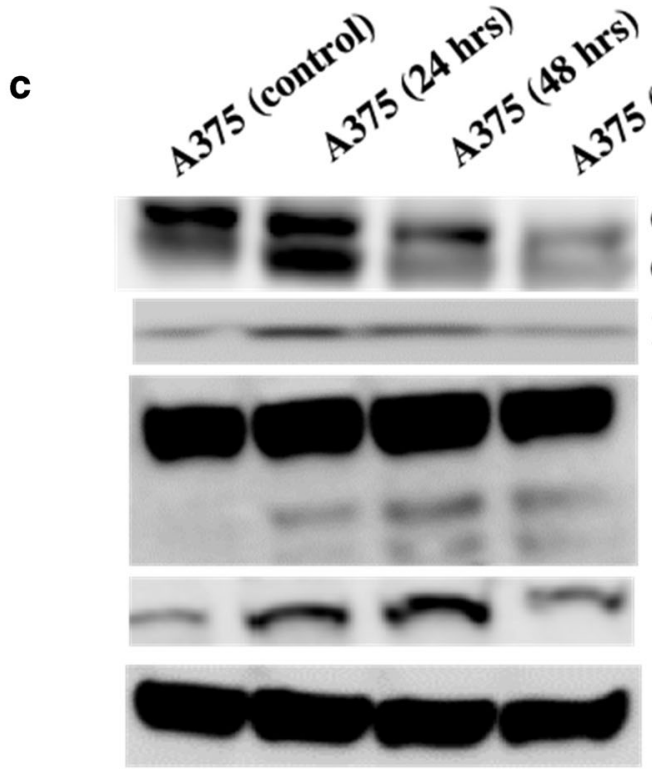

Fig. 6 The ability of compound 22 to induce apoptosis in A375 cells. Briefly, cells were exposed to $100 \mu \mathrm{M}$ of compound 22 at 24,48 and $72 \mathrm{~h}$ and then the number of live, apoptotic and necrotic cells were recorded by means of (a) flow cytometry and also quantified as (b) percent of total cell population. Data shown are means \pm SD of 3 replicates from three independent experiments. Asterisks $(* *)$ and $(* * *)$ denote statistical

melanogenesis could potentially improve the therapeutic outcome of radiotherapy $[64,65]$.

On another note, hydroquinone core-based precursors of melanin can act as redox cyclers mainly in the presence of iron species [66-68]. Previously, it has been shown that combinational therapy with metal chelators and Celecoxib (a drug acting as a COX-2 inhibitor) can dramatically suppress metastatic melanoma by inhibiting COX-2 associated cell significance at $\mathrm{p}<0.01$ and $\mathrm{p}<0.001$ respectively when compared to their respective control (untreated cells); (c) The ability of compound 22 to induce the expression of intrinsic and extrinsic apoptotic markers in A375 cells. Cells were subjected to $100 \mu \mathrm{M}$ of compound 22 for 24,48 and $72 \mathrm{~h}$ and protein expression levels of full length and cleaved caspases- 8 and -9 were recorded in addition to those of BID and Apaf- 1

signalling pathway(s) [69]. Additionally, other experimental studies have shown that melanoma cells produce large amounts of extracellular superoxide anion (compared to normal melanocytes) suggesting that they are constantly exposed to an oxidative stress environment induced by elevated levels of intracellular ROS [70]. To this end, we have demonstrated that treatment with $100 \mu \mathrm{M}$ of compound 22 stimulates the production of intracellular ROS (by approximately 4-fold) 

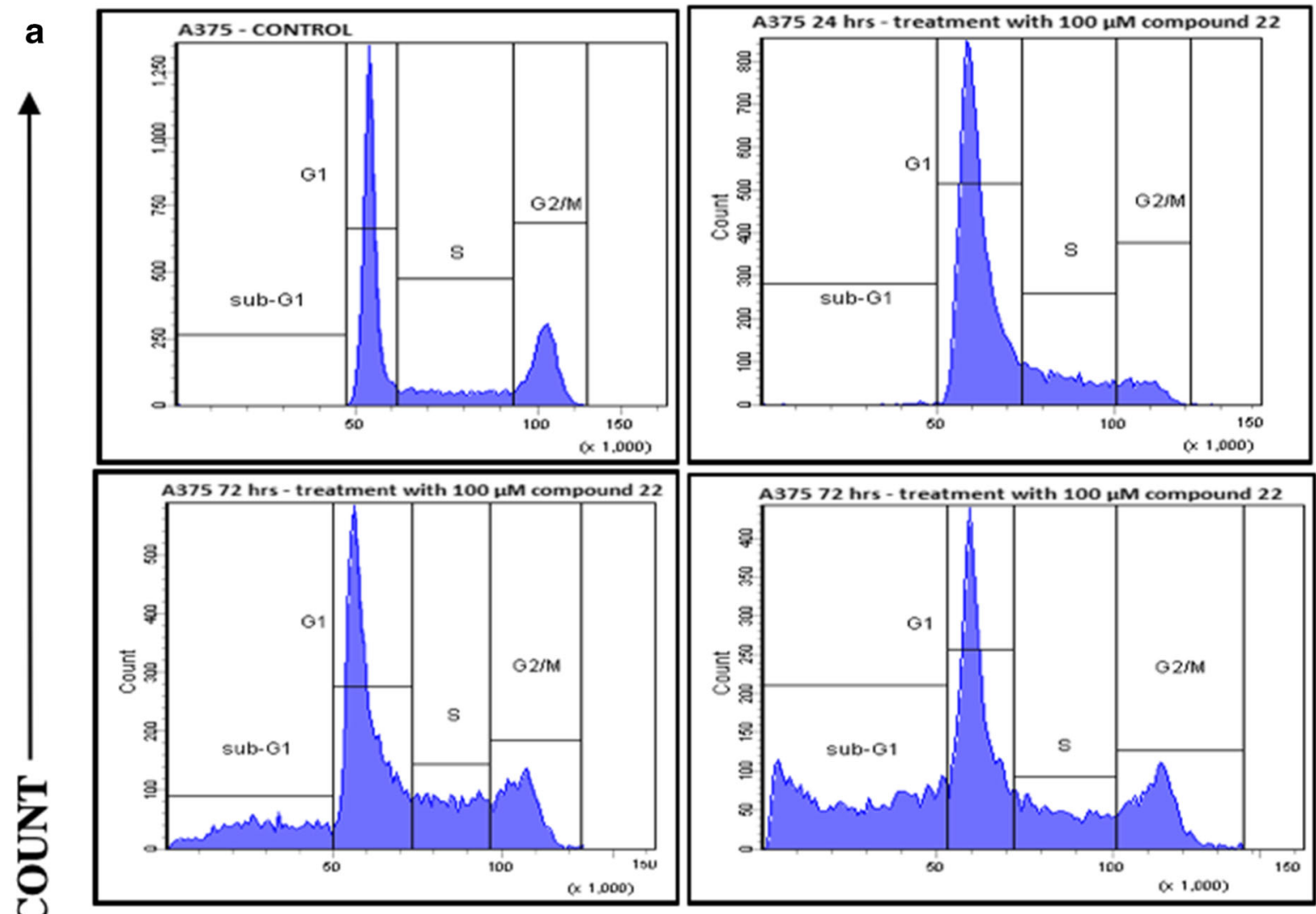

PI

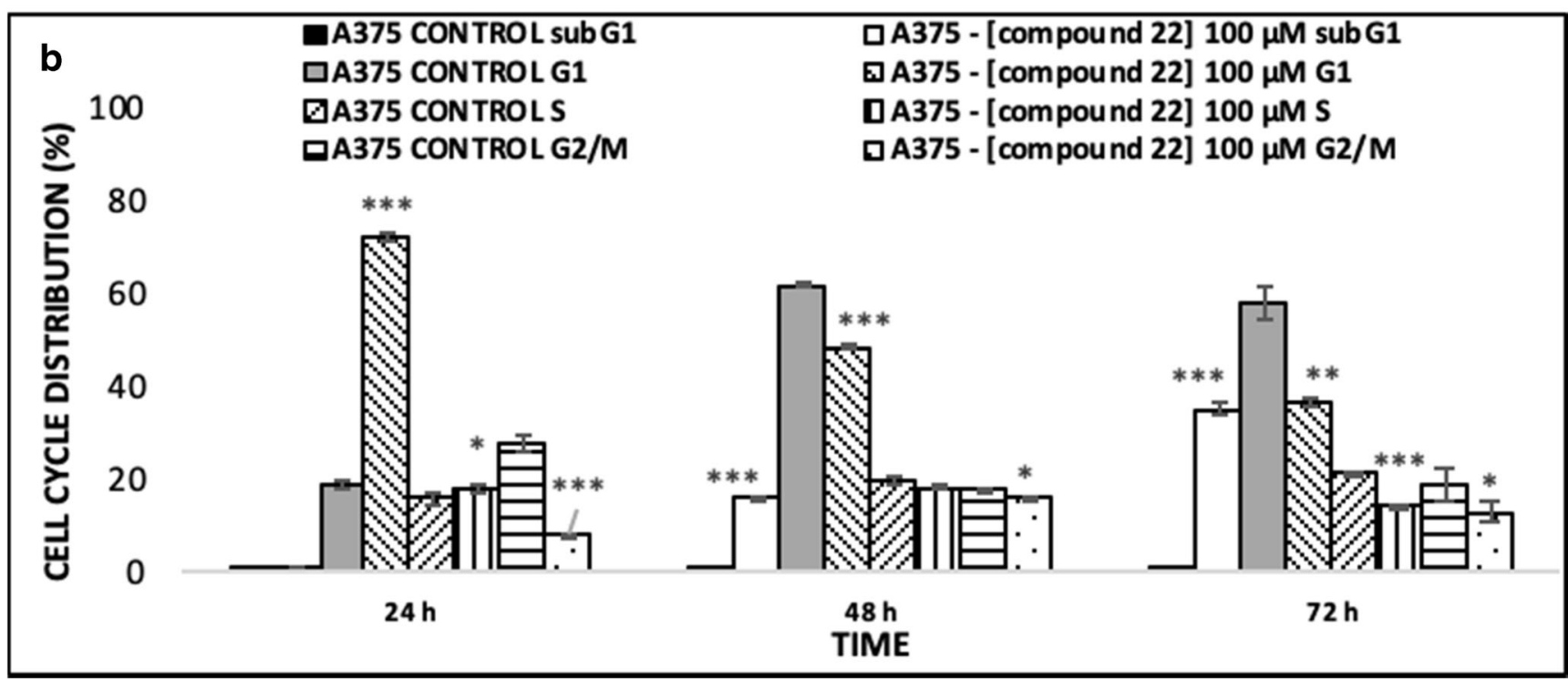

Fig. 7 The ability of compound 22 to induce cell cycle growth arrest in A375 cells. Cells were exposed to $100 \mu \mathrm{M}$ of compound 22 at 24,48 and $72 \mathrm{~h}$ and then the number of cells were recorded at each stage of the cell cycle by means of (a) flow cytometry and also quantified as (b) percent of total DNA cellular content accumulated at each phase of the cell cycle (e.g. sub-G1, G1, S or G2/M). Data shown are means \pm SD of 3 replicates from three independent experiments. Asterisks $(* * *)$ denote statistical significance at $p<0.01$ and $p<0.001$ respectively when compared to their respective control (untreated cells) 
compared to the untreated control, at $24 \mathrm{~h}$ post-treatment, and this effect was retained over the entire time-course. Despite the fact that HOPOs are known to acts as antioxidants, compound 22 has been shown to induce generation of ROS presumably as a consequence of pro-oxidant effects [71, 72]. Nevertheless, this finding is in agreement with another study utilizing glioma cells treated with $L$-mimosine during which the authors observed apoptotic induction as the result of the release of mitochondria-derived ROS together with activation of p38 and JNK [73]. Finally, another study has shown that a different class of metal chelators (i.e. thiosemicarbazones) have the ability to induce cytotoxicity on melanoma cells by disrupting the cellular antioxidant defence system thus causing elevation of intracellular ROS levels [74].

In investigating further into the anti-proliferative effect(s) of compound 22, we focused our efforts into the mode of cell death activation. Our findings revealed triggering of apoptosis evident by the induction of both extrinsic and intrinsic cascades (via activation of caspases- 8 and -9 respectively) suggesting that compound 22 induces apoptosis in a similar manner to $L$-mimosine $[73,75,76]$. To this end, another study has shown that melanoma cells induce apoptosis in response to treatment with metal chelators in an attempt to compensate for an increased load of ROS [77]. On the other hand, ROS can act as second messengers capable of regulating several diverse cellular functions including cell survival and proliferation [78]. Therefore, elevated levels of ROS can trigger the activation of caspases thus initiating apoptosis. In fact, lower ROS concentrations have been shown to induce cell survival responses whereas higher ones can activate death processes including apoptosis [79]. Last but not least, metal chelators can inhibit cell growth by either inducing apoptosis such as in Kaposi sarcoma cells [80] and/or by blocking cell cycle progression like in the cases of breast [32] and lung [81] cancer cells. To our knowledge, this is the first report that (i) presents the screening of newly synthesized hydroxypyridinone-based analogues of $L$ mimosine and also (ii) describes how compound 22 exerts its anticancer activity against an in vitro model of human malignant melanoma. This is of utmost importance as there is a great need to synthesize novel metal chelators with the capacity to minimize side-effects and increase therapeutic effectiveness. In the clinical setting, this is of particular interest as it could potentially translate into better therapeutic management and consequently better quality of life in these patients.

Acknowledgments The authors would like to thank Dr. Sharon Broby (Dermal Toxicology \& Effects Group; Centre for Radiation, Chemical and Environmental Hazards; Public Health England, UK) for kindly providing the human immortalized keratinocyte (HaCaT) cell line and Dr. Sharon Cookson for her technical support in flow cytometry experiments.
Funding This work was supported by start-up funds (MIP) including $\mathrm{PhD}$ studentships (SK \& MM) provided by the Multi-Disciplinary Research Theme in "Bio-economy" of Northumbria University.

\section{Compliance with ethical standards}

Conflict of interest The author Sotiris Kyriakou declares that he has no conflict of interest. The author Melina Mitsiogianni declares that she has no conflict of interest. The author Theodora Mantso declares that she has no conflict of interest. The author William Cheung declares that he has no conflict of interest. The author Stephen Todryk declares that he has no conflict of interest. The author Stephany Veuger declares that she has no conflict of interest. The author Aglaia Pappa declares that she has no conflict of interest. The author David Tetard declares that he has no conflict of interest. The author Mihalis I. Panayiotidis declares that he has no conflict of interest.

Ethical approval This article does not contain any studies with human participants or animals performed by any of the authors.

Informed consent For this type of study, formal consent is not required.

Open Access This article is distributed under the terms of the Creative Commons Attribution 4.0 International License (http:// creativecommons.org/licenses/by/4.0/), which permits unrestricted use, distribution, and reproduction in any medium, provided you give appropriate credit to the original author(s) and the source, provide a link to the Creative Commons license, and indicate if changes were made.

\section{References}

1. Orthaber K, Pristovnik MM, Skok K, Perić B, Maver UU (2017) Skin Cancer and its treatment: novel treatment approaches with emphasis on nanotechnology. J Nanomater 2017:1-20

2. Savage $P$ (2007) Malignant Melanoma (Non-Metastatic). BMJ Clin Evid 2007:1705

3. Rastrelli M, Tropea S, Rossi CR, Alaibac M (2014) Melanoma: epidemiology, risk factors, pathogenesis, diagnosis and classification. In Vivo 28(6):1005-1011

4. Zbytek B, Carlson JA, Granese J, Ross J, Mihm MC Jr, Slominski A (2008) Current concepts of metastasis in melanoma. Expert Rev Dermatol 3(5):569-585

5. Gupte A, Mumper RJ (2009) Elevated copper and oxidative stress in Cancer cells as a target for Cancer treatment. Cancer Treat Rev 35(1):32-46

6. Denoyer D, Masaldan S, La Fontaine S, Cater MA (2015) Targeting copper in Cancer therapy: "copper that cancer". Metallomics 7(11): 1459-1476

7. De Wever O, Derycke L, Hendrix A, De Meerleer G, Godeau F, Depypere H, Bracke M (2007) Soluble Cadherins as cancer biomarkers. Clin Exp Metastasis 24(8):685-697

8. Tang MKS, Yue PYK, Ip PP, Huang R-L, Lai H-C, Cheung ANY, Tse KY, Ngan HYS, Wong AST (2018) Soluble E-cadherin promotes tumor angiogenesis and localizes to exosome surface. Nat Commun 9(1):1-15

9. Thomas C, Mackey MM, Diaz AA, Cox DP (2009) Hydroxyl radical is produced via the Fenton reaction in submitochondrial particles under oxidative stress: implications for diseases associated with Iron accumulation. Redox Rep 14(3):102-108

10. Fouani L, Menezes SV, Paulson M, Richardson DR, Kovacevic Z (2017) Metals and metastasis: exploiting the role of metals in cancer 
metastasis to develop novel anti-metastatic agents. Pharmacol Res 115:275-287

11. Cichon MA, Radisky DC (2014) ROS-induced epithelial-mesenchymal transition in mammary epithelial cells is mediated by NFkB-dependent activation of Snail. Oncotarget 5(9):2827-2838

12. Park SY, Yoon SJ, Hakomori S, Jeong YT, Kim JM, Kim JY, Bernert B, Ullman T, Itzkowitz SH, Kim JH, Hakomori SI (2010) $\mathrm{N}$-glycosylation status of beta-haptoglobin in sera of patients with colon cancer, chronic inflammatory disease and normal subjects. Int J Oncol 36(5):1291-1297

13. Morgan MJ, Liu Z (2011) Crosstalk of reactive oxygen species and NF- $\kappa$ B signalling. Cell Res 21(1):103-115

14. Agrawal A, Romero-Perez D, Jacobsen JA, Villarreal FJ, Cohen SM (2008) Zinc-binding groups modulate selective inhibition of MMPs. Chem Med Chem 3(5):812-820

15. Itoh T, Tanioka M, Yoshida H, Yoshioka T, Nishimoto H, Itohara S (1998) Reduced angiogenesis and tumor progression in gelatinase A-deficient mice. Cancer Res 58(5):1048-1051

16. Buss JL, Torti FM, Torti SV (2003) The role of Iron chelation in cancer therapy. Curr Med Chem 10:1021-1034

17. Simões RV, Veeraperumal S, Serganova IS, Kruchevsky N, Varshavsky J, Blasberg RG, Ackerstaff E, Koutcher JA (2017) Inhibition of prostate cancer proliferation by Deferiprone. NMR Biomed 30(6):1-11

18. Salis O, Bedir A, Kilinc V, Alacam H, Gulten S, Okuyucu A (2014) The anticancer effects of Desferrioxamine on human breast adenocarcinoma and hepatocellular carcinoma cells. Cancer Biomark 14(6):419-426

19. Zhao R, Planalp RP, Ma R, Greene BT, Jones BT, Brechbiel MW, Torti FM, Torti SV (2004) Role of zinc and Iron chelation in apoptosis mediated by Tachpyridine, an anti-cancer Iron chelator. Biochem Pharmacol 67(9):1677-1688

20. Rejmund M, Mrozek-Wilczkiewicz A, Malarz K, Pyrkosz-Bulska M, Gajcy K, Sajewicz M, Musiol R, Polanski J (2018) Piperazinyl fragment improves anticancer activity of Triapine. PLoS One 13(4): $1-25$

21. Richardson DR, Milnes K (1997) The potential of Iron chelators of the pyridoxal Isonicotinoyl Hydrazone class as effective Antiproliferative agents II: the mechanism of action of ligands derived from salicylaldehyde benzoyl hydrazone and 2-Hydroxy-1Naphthylaldehyde benzoyl Hydrazone. Blood 89(8):3025-3038

22. Schwab M (2011) Chelators as anti-Cancer drugs. In: Schwab M (ed) Encyclopedia of cancer. Springer, Berlin, Heidelberg, pp 755-759

23. Abeysinghe RD, Roberts PJ, Cooper CE, MacLean KH, Hider RC, Porter JB (1996) The environment of the lipoxygenase Iron binding site explored with novel Hydroxypyridinone Iron chelators. J Biol Chem 271(14):7965-7972

24. Liu ZD, Lockwood M, Rose S, Theobald AE, Hider RC (2001) Structure-activity investigation of the inhibition of 3Hydroxypyridin-4-ones on mammalian tyrosine hydroxylase. Biochem Pharmacol 61(3):285-290

25. Tricta F, Uetrecht J, Galanello R, Connelly J, Rozova A, Spino M, Palmblad J (2016) Deferiprone-induced agranulocytosis. Am J Hematol 91(10):1026-1031

26. Kontoghiorghe CN, Kolnagou A, Kontoghiorghes GJ (2015) Phytochelators intended for clinical use in Iron overload, other diseases of Iron imbalance and free radical pathology. Molecules 20(11):20841-20872

27. Nguyen BCQ, Tawata S (2016) The chemistry and biological activities of Mimosine: a review. Phytother Res 30:1230-1242

28. DeWys WD, Hall TC (1973) Anti-tumor effect of the amino acid Mimosine. Eur J Cancer 9(4):281-283

29. Cabanes J, Garcia-Canovas F, Tudela J, Lozano JA, GarcíaCarmona F (1987) L-mimosine a slow-binding inhibitor of mushroom Tyrosinase. Phytochemistry 26(4):917-919
30. Soedarjo M, Borthakur D (1996) Simple procedures to remove Mimosine from young leaves, pods and seeds of Leucaena Leucocephala used as food. Int J Food Sci Technol 31(1):97-103

31. Vogt G, Böhm R, Segner H (1994) Mimosine-induced cell death and related chromatin changes. J Submicrosc Cytol Pathol 26(3): 319-330

32. Kulp KS, Vulliet PR (1996) Mimosine blocks cell cycle progression by chelating Iron in asynchronous human breast cancer cells. Toxicol Appl Pharmacol 139(2):356-364

33. Park SY, Im JS, Park SR, Kim SE, Wang HJ, Lee JK (2012) Mimosine arrests the cell cycle prior to the onset of DNA replication by preventing the binding of human Ctf4/And-1 to chromatin via Hif- $1 \alpha$ activation in HeLa cells. Cell Cycle 11(4):761-766

34. Vogt G, Böhm R, Segner H (1993) Mimosine, a naturally occurring drug interfering primarily with the cell nucleus. J Submicrosc Cytol Pathol 25(2):247-256

35. Gilberts D, Neilson A, Miyazawa H, De Pamphilis M, Burhans W (1995) Mimosine arrests DNA synthesis at replication fork by inhibiting Deoxyribonucleotide metabolism. J Biol Chem 270(16):9597-9606

36. Dai Y, Gold B, Vishwanatha JK, Rhode SL (1994) Mimosine inhibits viral DNA synthesis through ribonucleotide reductase. Virology 205(1):210-216

37. Perry C, Sastry R, Nasrallah IM, Stover PJ (2005) Mimosine attenuates serine Hydroxymethyltransferase transcription by chelating zinc: implications for inhibition of DNA replication. J Biol Chem 280(1):396-400

38. Lin H, Falchetto R, Mosca PJ, Shabanowitz J, Hunt DF, Hamlin JL (1996) Mimosine targets serine Hydroxymethyltransferase inhibitor of DNA replication in mammalian cells. J Biol Chem 271(5):2548-2556

39. Hallak M, Dvilansky A, Shpilberg O, Levi I, Mazar J, Nathan I (2004) Mimosine induces apoptosis through metal ion chelation, mitochondrial activation and reactive oxygen species production in human leukemic cells. Blood 104:4481

40. Prabhakaran K, Harris EB, Kirchheimer WF (1973) A specific effect of Mimosine on Melanoma cells. Cytobios 7:245-252

41. Khwaja TA, Hall TC, Sheikh KMA (1976) Antitumor activity of Mimosine and Mimosine hydrochloride against B16 melanoma in BDF mice. In: Hellmann K, Connors TA (eds) Chemotherapy, vol 8. Springer, Boston

42. Prabhakaran K, Harris EB, Kircheimer WF (1969) Suppression of melanoma development and inhibition of phenoloxidase by mimosine. Cytobios 1A:3-5

43. Fraga S, Serrão MP, Soares-da-Silva P (2002) L-type amino acid transporters in two intestinal epithelial cell lines function as exchangers with neutral amino acids. J Nutr 132(4):733-738

44. Augustyn E, Finke K, Zur AA, Hansen L, Heeren N, Chien HC, Lin L, Giacomini KM, Colas C, Schlessinger A, Thomas A (2016) LAT-1 activity of meta substituted phenylalanine and tyrosine analogs. Bioorg Med Chem Lett 26:2616-2621

45. Chien HC, Colas C, Finke K, Springer S, Stoner L, Zur AA, Venteicher B, Campbell J, Hall C, Flint A, Augustyn E, Hernandez C, Heeren N, Hansen L, Anthony A, Bauer J, Fotiadis D, Schlessinger A, Giacomini KM, Thomas AA (2018) Reevaluating the substrate specificity of the L-type amino acid transporter (LAT1). J Med Chem 61:7358-7373

46. Geier EG, Schlessinger A, Fan H, Gable JE, Irwin JJ, Sali A, Giacomini KM (2013) Structure-based ligand discovery for the large-neutral amino acid transporter 1 LAT-1. Proc Natl Acad Sci U S A 110:5480-5485

47. Lin J, Raoof DA, Thomas DG, Greenson JK, Giordano TJ, Robinson GS, Bourner MJ, Bauer CT, Orringer MB, Beer DG (2004) L-type amino acid Transporter-1 overexpression and Melphalan sensitivity in Barrett's adenocarcinoma. Neoplasia 6(1):74-84 
48. Green RD (2017) Cell death and the immune system: getting to how and why. Immunol Rev 277:76-89

49. Fulda S (2015) Targeting extrinsic apoptosis in cancer: challenges and opportunities. Semin Cell Dev Biol 39:20-25

50. Kantari C, Walczak H (2011) Caspase- 8 and bid: caught in the act between death receptors and mitochondria. Biochim Biophys Acta 1813(4):558-563

51. Li P, Zhou L, Zhao T, Liu X, Zhang P, Liu Y, Zheng X, Li Q (2017) Caspase-9: structure, mechanism and clinical application. Oncotarget 8(14):23996-24008

52. Shakeri R, Kheirollahi A, Davoodi J (2017) Apaf-1: regulation and function in cell death. Biochimie 135:111-125

53. Yuan S, Akey CW (2013) Apoptosome structure, assembly and procaspase activation. Structure 21(4):501-515

54. Zhou M, Li Y, Hu Q, Bai X, Huang W, Yan C, Scheres SH, Shi Y (2015) Atomic structure of the apoptosome: mechanism of cytochrome c- and dATP mediated activation of Apaf-1. Genes Dev 29(22):2349-2361

55. Hu Q, Chen W, Zhen Y, Shi Y (2013) Proteolytic processing of the caspase-9 zymogen is required for Apoptosome-mediated activation of caspase. J Biol Chem 288(21):15142-15147

56. Würstle ML, Rehm M (2014) A systems biology analysis of apoptosome formation and apoptosis execution supports allosteric procaspase-9 activation. J Biol Chem 289(38):26277-26289

57. Yuan S, Yu X, Asaram JM, Heuser JE, Ludtke SL, Akey CW (2011) The holo-apoptosome: activation of procaspase-9 and interactions with caspase-3. Structure 19:1084-1096

58. Wright KM, Deshmukh M, Vaughn AE (2007) Apoptosome dependent caspase-3 activation pathway is non-redundant and necessary for apoptosis in sympathic neurons. Cell Death Differ 14:625-633

59. Zou H, Yang R, Hao J, Wang J, Sun C, Fesik SW, Wu JC, Tomaselli KJ, Armstrong RCJ (2003) Regulation of the Apaf-1/Caspase-9 apoptosome by Caspase-3 and XIAP. J Biol Chem 278(10):8091-8098

60. Kang YJ, Kuo C-F, Majd S (2017) Nanoparticle-based deliver of an anti-proliferative metal chelator to tumor cells. IEEE:309-312

61. Tsuma-Kaneko M, Sawanobori M, Kawakami S, Uno T, Nakamura Y, Onizuka M, Ando K, Kawada H (2018) Iron removal enhances vitamin $\mathrm{C}$-induced apoptosis and growth inhibition of K-562 leukemic cells. Sci Rep 8:17377

62. Xu LL, Hu PP, Kong X, Hider RC, Zhou T, Dai ZY (2014) 3Hydroxypyridinone-l-phenylanaline conjugates with antimicrobial and tyrosinase activities as potential shrimp preservatives. Int J Food Sci Technol 49(3):797-803

63. Slominski RM, Zmijewski MA, Slominski AT (2015) The role of melanin pigment in melanoma. Exp Dermatol 24:258-259

64. Slominski A, Zmijewski MA, Pawelek J (2012) L-tyrosine and Ldihydroxyphenylalanine as hormone-like regulators of melanocyte fuctions. Pigment Cell Melanoma Res 25:14-27

65. Brozyna AA, Jozwicki W, Roszkowski K, Filipiak J, Slominski AT (2016) Melanine content in melanoma metastases affects the outcome radiotherapy. Oncotarget 7:17844-17853

66. Prota G, D'Jschia M, Mascagna D (1994) Melanogenesis as a targeting strategy against metastatic melanoma: a reassessment. Melanoma Res 4:351-358

67. Novellino L, Napolitano A, Prota G (1999) 5,6-Dihydroxyindoles in the Fenton chemistry: a model study of melanin precursors in oxidative stress and hyperpigmentary processes. Chem Res Toxicol 12:985-992

68. Inbaraj J, Gandhidasan R, Murugesan R (1999) Cytotoxicity and superoxide anion generation by some naturally occurring quinones. Free Radic Biol Med 26:1072-1078

69. Zhou P, Qin J, Li Y, Li G, Wang Y, Zhan N, Chen P, Li C (2017) Combination therapy of $\mathrm{PKC} \zeta$ and $\mathrm{COX}-2$ inhibitors synergistically suppress melanoma metastasis. JECCR 36(115):1-12

70. Meyskens FL, McNulty SE, Buckmeier JA, Tohidian NB, Spillane TJ, KAhlon RS, Gonzales RI (2001) Aberrant redox regulation in human malignant metastatic melanoma cells compare to normal melanocytes. Free Radic Biol Med 31(6):799-808

71. Mohammadpour M, Sadeghi A, Fassihi A, Saghaie L (2012) Synthesis and antioxidant evaluation of some novel ortho-hydroxypyridine-4-one iron chelators. Res Pharm Sci 7(3):171-179

72. Lu N, Chen W, PEng YY (2011) Effects of glutathione, Trolox and desferrioxamine on hemoglobin induced protein oxidative damage: anti-oxidant or pro-oxidant? Eur J Pharmacol 659(2-3):95-101

73. Qiao S, Murakami K, Zhao Q, Wank B, Seo H, Yamashita H, Li X, Iwamoto T, Ichiharam M, Yoshino M (2012) Mimosine-induced apoptosis in C6 glioma cells requires the release of mitochondriaderived reactive oxygen species and p38. JNK activation. Neurochem Res 37:412-427

74. Akladios FN, Andrew SD, Parkinson CJ (2016) Investigation of the cytotoxic implications of metal chelators against melanoma and approaches to improve the cytotoxic profiles of metal coordinating agents. Biometals 29(5):789-805

75. Xu Y, Cai L (2018) L-mimosine induces caspase-9-mediated apoptosis in human osteosarcoma cells. Mol Med Rep 17:4695-4701

76. Zalatnai A, Bocsi J (2003) Mimosine, a plant-derived amino acid induces apoptosis in human pancreatic cancer xenografts. Anticancer Res 23:4007-4009

77. Meyskens FL, McNulty SE, Buckmeier JA, Tohidian NB, Spillane TJ, KAhlon RS, Gonzales RI (2001) Aberrant redox regulation in human malignant metastatic melanoma cells compared to normal melanocytes. Free Radic Biol Med 31(6):799-808

78. Sauer H, Wartenberg M, Hescheier J (2001) Reactive oxygen species as intracellular messengers during cell growth and differentiation. Cell Physiol Biochem 11(4):173-186

79. Redza-Dutordoir M, Averill-Bates DA (2016) Activation of apoptosis signalling pathways by reactive oxygen species. Biochim Biophys Acta 1863(12):2977-2992

80. Simonart T, Degraef C, Andrei G, Mosselmans R (2000) Iron chelators inhibit the growth and induce the apoptosis of Kaposi's sarcoma cells and of their putative endothelial precursors. J Invest Dermatol 115(5):893-900

81. Chang HC, Lee TH, Chuang LY, Yen MH, Hung WC (1999) Inhibitory effect of mimosine on proliferation of human lung cancer cells is mediated by multiple mechanisms. Cancer Lett 145:1-8

Publisher's note Springer Nature remains neutral with regard to jurisdictional claims in published maps and institutional affiliations. 